International Review of Research in Open and Distributed Learning Volume 17, Number 4

June -2016

\title{
Use of Facebook by Secondary School Students at Nuku'alofa as an Indicator of E-Readiness for E-Learning in the Kingdom of Tonga
}

\author{
Hans T, Sopu, Yoshifumi Chisaki, and Tsuyoshi Usagawa \\ Kumamoto University, Japan
}

\begin{abstract}
The Kingdom of Tonga is an isolated least developing country located on the northeast of New Zealand with a population of 103,252 (2011 census) and with a gross domestic product per capita of USD $\$ 2,545.20$. Before educational systems in a least developing country like the Kingdom of Tonga begin employing e-learning, an assessment of the current situation of students and learning institutions may contribute to its success. Using an appropriate assessment tool is important for accurately measuring the degree of e-readiness. In this study, we administered a survey to 186 students randomly selected from five secondary schools in the Kingdom of Tonga to measure Facebook usage as an index of e-readiness for elearning. We found that a large percentage (81\%) of secondary students use Facebook, and most (74\%) of these students have used Facebook for two or more years. All (100\%) students use a computer to access Facebook, and most also access Facebook through mobile phones (62\%) or tablets (46\%). We also found correlations between duration of having a Facebook account and other indicators of e-readiness. Our findings suggest that secondary students in the Kingdom of Tonga have developed e-readiness for elearning through their use of Facebook.
\end{abstract}

Keywords: Facebook, e-learning, Kingdom of Tonga, e-readiness, secondary education, developing countries

\section{Introduction}

Electronic readiness, also known as e-readiness, is a measure of the degree to which a nation, country, or economy may be ready, willing, or prepared to obtain benefits from information and communication technology (ICT), such as that used in e-commerce, e-learning, or e-government. For instance, before educational systems in a country begin employing e-learning, an assessment of the current e-activities of students and learning institutions may contribute to its success. Typically, the e-readiness of a country is assessed based on its percentage of Internet users, Internet subscribers, or mobile cellular subscribers, and e-readiness measures can be compared across countries or analyzed within a single country (Ghavamifar, Beig, \& Montazer, 2008; Bridges.org, 2005). 
The first model of e-readiness, known as the "Guide to Global Electronic Commerce Readiness," was developed by the Computer System Policy Project (CSPP currently known as Technology CEO Council) in 1999 (Technology CEO Council, 2016) . This model uses 22 multiple-choice questions to measure seven indicators of network readiness: backbone, demand, residential or small business services, large business services, residential or small business affordability, large business affordability, and quality of service. After the CSPP guide, as mentioned by Rizk (2004), there are other models including McConnell International, the Network Readiness Index tool from the Center for International Development at Harvard University, the E-Readiness Rankings from the Economist Intelligent Unit (Economist Intelligence Unit, 2005), the ICT Development Index from the United Nations Conference on Trade and Development, and the Framework to Assess Diffusion of the Internet from the Mosaic Group All of these tools measure e-readiness at the national level across key sectors of the economy, and the tools generally use different definitions of e-readiness and different measurement techniques (Bridges.org, 2001). For instance, the e-readiness ranking model from the Economist Intelligence Unit (2005) focuses mainly on ICT in businesses.

E-readiness rankings are particularly important for developing countries with the potential to take advantage of ICT. For instance, the Economist Intelligence Unit Report lists Australia, Singapore, New Zealand, and Hong Kong among the countries with the highest e-readiness but gave low rankings to countries like India and China, even though these countries are among the largest and fastest growing consumers and producers of ICT. Based on the original CSPP model, "Readiness for the Networked World" (Centre for International Development, 2000) is a guide for developing countries created by the Center for International Development at Harvard University. Its objective is to bring awareness of how developing countries would benefit from using ICT and to act as a guide for future efforts to unlock the tremendous potential that ICT, such as that used in e-learning, holds as a catalyst for development. To successfully implement e-learning, however, an assessment of e-readiness must take place.

Adopting the proper e-readiness tools for developing countries helps cut cost, time and effort (Beig, Montazer, \& Gavarmifar, 2007). Maugis et al., (2005) claim that most e-readiness indices are fraught with uncertainties and ambiguities in both theory and practice and assume a fixed, one-size-fits-all set of requirements that do not consider the unique characteristics of individual countries, resulting in a large gap between theoretical frameworks and practical implications. Maugis et al. also claim that there are three domains or aspects of e-readiness: access, capacity, and opportunities. If access conditions are in place, then capacity considerations come into play. If both access and capacity are in place, then value creation opportunities can be pursued (Bui, Sankaran, \& Sebastian, 2003; Machado, 2007; Molla et al., 2008; Mutula \& van Brakel, 2006). In this study, we focus on the social aspect of e-readiness, measuring the e-readiness for e-learning of the users, focusing on students only. Other users' e-readiness such as teachers and administrations are not included. Assessing the proper environment and ICT infrastructure (capacity) for e-learning is also not included in this study.

Picci (2006) states that having a quantifiable set of indicators or using an appropriate e-readiness assessment tool can provide a broad overview of a country's situation and form the basis of comparison with other countries and future planning. As a real-world example, Purcell and Toland (2004) found that although the Internet was widely adopted on the South Pacific island of Samoa, e-commerce had not 
contributed significantly to its economy. That is, even though the technology was widely available, people were still not e-ready for e-commerce. They discussed four things that prevented the development of ecommerce: (a) limited human resources, (b) lack of awareness of the benefits of e-commerce, (c) poor institutional capacity, and (d) high cost of information management systems. Dada (2006) concluded that assessment tools may provide a useful overview of the e-readiness of developing countries but do not completely reflect the possibility of employing ICT. To measure e-readiness more accurately, Dada suggests that the focus of assessments should be moved from countries to individual users. Vaezi and Bimar (2009) also suggest end-user analysis because existing assessment tools are either limited in scope or lack detailed description on how to use the tool in practice. They conclude that an e-readiness tool must be designed according to the user's goal. Although there are many e-readiness assessment tools, including other works described in the literature that could be adopted as e-readiness assessment tools, their focus is on the infrastructure of countries rather than on individuals. Mow (2014) recommends the awareness of the use of social networking among people of the Pacific Islands. .

The Island of Tonga is an isolated small island nation located in the South Pacific, northeast of New Zealand with Gross Domestic Product per capita of \$2,545.20 (USD) as of the end of 2014 (World bank, 2014). With a population of 103,252 (2011 Census Statistics), $73 \%$ of the total population inhabited the main island of Tongatapu where the capital city of Nuku'alofa is located. About $19 \%$ of the people of Tongatapu were between the ages of 15 to 24. There were 22 secondary schools (Year 1 to Year 6 with no e-learning system) with an Internet access not available for the students (TDoS, 2011). There were also about 10 tertiary institutions (no e-learning system) and with no university owned by the Kingdom of Tonga. However, a branch of the University of the South Pacific (headquarter in Fiji) is the only learning institution with an e-learning system using the Moodle platform. In 2012, a trial of an e-learning system was put in place in one of the secondary schools (government owned) approved by the Ministry of Education of the Kingdom of Tonga (Sopu, Chisaki, \& Usagawa, 2013). The school had only one computer lab with seven computers connected to the Internet. The trial faced challenges such as lack of computers and no Internet devices and low Internet bandwidth. The Socialbaker website (2014) indicates that Facebook, which started in 2004, was the most used online social network in the Kingdom of Tonga at the end of 2013. About 39.5\% of the ages 15 to 24 were Facebook users. Sopu, Chisaki, and Usagawa (2014) found that many students in secondary schools in the Kingdom of Tonga were familiar with the Facebook platform such as comment, uploading pictures, and chat features, with most students (49\%) favoring the comment feature. These students did not have academic requirements involving the Internet but instead use the Internet for personal interest, such as for social networking. Several studies concluded with the recommendation of the usage of Facebook as part of the educational tools should be embraced, they even concluded with some evidence of the effectiveness of Facebook groups for e-learning (Chou \& Pi, 2015; Eger, 2015; Fewkes \& McCabe, 2012; Gu, 2014; Kumpikaite, Duoba, \& Taraskevicius, 2011; Teo \& Wong, 2013).

Few e-readiness assessments have been conducted in the Kingdom of Tonga. According to a survey conducted by the United Nations (2014) on the degree of e-government among its member countries, 34\% of government employees in the Kingdom of Tonga use the Internet, but only $0.10 \%$ of government employees subscribe to wireless broadband, indicating that wireless access is not widely available. However, $53 \%$ of government employees have mobile cellular broadband subscriptions, and these mobile 
devices (e.g., smartphones) may have wireless or cellular data connection capability. Commonwealth Connects (2007) reports that $60 \%$ of businesses in the Kingdom of Tonga use computers, but only $10 \%$ of businesses use the Internet. In addition, most ICT-related equipment (95\%) used by businesses in the Kingdom of Tonga is imported.

A decade ago, 10 pacific islands gathered for discussion on ICT in education (University of South Pacific, 2005). Only one pacific island came with the idea of e-learning. At the time, the Island of Tonga focused primarily on implementing a Computer Study course throughout the secondary schools. As of June 2014, the Ministry of Education had no plan for implementing e-learning due to lack of resources, expertise, and especially the idea of where to start (Catherwood, Levine, \& Ministry of Education Planning Group, 2004).

The lack of data on indications of e-readiness among secondary students in the Kingdom of Tonga makes it unclear whether students are e-ready for e-learning. A previous survey concluded that most of the educators who participated in the survey agreed to the idea of e-learning to be part of the educational system of the Kingdom of Tonga (Sopu, Chisaki, \& Usagawa, 2012). Therefore, this study aimed to observe the Facebook usage among secondary students only in the Kingdom of Tonga as an indications of the degree of e-readiness for e-learning. However, this study alone is not an indication that secondary students are ready or even willing to move towards e-learning. Hence, we had the following objectives:

- To determine the number of secondary students who currently use Facebook,

- To measure students' patterns of Facebook usage, and

- To use students' Facebook usage as a tool to indicate the skills of the students related to ereadiness for e-learning.

\section{Method}

\section{Survey Questionnaire}

The survey contained 25 questions consisting of closed-ended and open-ended questions, Likert-scale questions, and multiple-choice questions.

\section{Research Conceptual Framework}

Our research framework consisted of four items: (a) Facebook, (b) users, (c) access, and (d) capacity. We focused on use of the Internet and Internet devices and familiarity with the Facebook platform or the perceived skills of the students. We based our research framework on the United Nations Educational, Scientific and Cultural Organization (UNESCO) definition of e-readiness: "e-readiness is not simply a matter of the number of computer servers, websites, and mobile phones in the country but also things such as its citizens' ability to utilize technology skillfully" (2006, p. 03). Therefore, we observed (through Facebook usage) the skillful utilization (i.e., capacity or indication) of ICT (i.e., access) by secondary students (i.e., users) in the Kingdom of Tonga. 
Facebook. We selected Facebook usage as an indicator of e-readiness for two reasons. First, Facebook is the most used online social network in the Kingdom of Tonga according to Socialbakers (2014) and Allin1Social (2014) websites (see Table 1). Second, previous studies claim that Facebook can be used for teaching due to its features and potential to enhance motivation for learning experiences (Goertler, 2009; Mason, 2006; Mazer, Murphy, \& Simonds, 2007). Facebook has recently been used by educators for e-learning due to its similarity to a learning management system (LMS) (Bradley, Holcomb, \& Smith, 2010; Meishar-Tal, Kurtz, \& Pieterse, 2012; Wang, Woo, Quek, Yang, \& Liu, 2011). Compared with YouTube and Twitter (Table 2), Facebook has more features similar to those of an LMS. Therefore, secondary students who are Facebook users may already have experience using these features.

Table 1

Usage of Online Social Networking Platforms in the Kingdom of Tonga as of June 2014

Online Social Networking Platform N N N N N $\quad$ Number of

Facebook (Source: www.allin1social.com) 21,000

Twitter (Source: www.socialbakers.com)

586

YouTube (Source:

www.channelgraphs.com)

169

Table 2

Features of an LMS and Online Social Networking Platforms

\begin{tabular}{ccccc}
\hline Feature & LMS & Facebook & YouTube & Twitter \\
\hline Tagging & $\checkmark$ & $\checkmark$ & $\checkmark$ & $\checkmark$ \\
Friends & $\checkmark$ & & $\checkmark$ \\
Wiki & $\checkmark$ & $\checkmark$ & & \\
File sharing & $\checkmark$ & $\checkmark$ & $\checkmark$ & $\checkmark$ \\
Blog & $\checkmark$ & (limited) & (limited) & (limited)
\end{tabular}




\begin{tabular}{ccccc}
$\begin{array}{c}\text { Create and } \\
\text { share content }\end{array}$ & $\checkmark$ & $\checkmark$ & $\checkmark$ & $\checkmark$ \\
$\begin{array}{c}\text { Online } \\
\text { discussion }\end{array}$ & $\checkmark$ & $\checkmark$ & $\checkmark$ & $\checkmark$ \\
$\begin{array}{c}\text { Manage } \\
\text { content }\end{array}$ & $\checkmark$ & $\begin{array}{c}\checkmark \\
\text { (limited) }\end{array}$ & $\checkmark$ & $\checkmark$ \\
Message & $\checkmark$ & $\checkmark$ & $\checkmark$ & $\checkmark$ \\
Chat & $\checkmark$ & $\checkmark$ & $\checkmark$ & $\checkmark$ \\
$\begin{array}{c}\text { Mobile } \\
\text { friendly }\end{array}$ & $\checkmark$ & $\checkmark$ & & \\
Groups & $\checkmark$ & $\checkmark$ & & \\
Assessments & $\checkmark$ & $\checkmark$ & -6 & -4 \\
$\begin{array}{c}\text { Missing } \\
\text { Feature(s) }\end{array}$ & & -1 & & \\
\hline
\end{tabular}

Note. Source: Bradley et al., 2010; Wang et al., 2011; Meishar-Tal et al., 2012.

Users. We selected secondary students in the Kingdom of Tonga as our target population because our future work aims to promote e-learning in secondary schools in this country. The Socialbakers and Allin1Social websites indicate that $10.8 \%$ and $36.1 \%$ of citizens between the ages of $13-17$ and 18-24, respectively, are Facebook users (Table 3). The age range of secondary students is between 13-20 years of age. As of December 2014, no secondary schools in the Kingdom of Tonga employed elearning systems. Although there are other aspects of e-readiness, in this study, we focus on measuring the e-readiness for e-learning on secondary students only.

Table 3

Age and Gender Distribution of Facebook users in the Kingdom of Tonga as of June 2014

\begin{tabular}{|cc|cc|}
\hline $\begin{array}{c}\text { Age } \\
\text { (Years) }\end{array}$ & $\%$ & Gender & $\%$ \\
$13-17$ & 10.8 & Male & 43.9 \\
$18-24$ & 36.1 & Female & 56.1 \\
\hline
\end{tabular}

25-34

31.6 
Note. Source: www.allin1social.com

Access. In this study, access refers to the Internet and Internet devices. In the Kingdom of Tonga, students are not allowed to access the Internet or to use mobile phones or smart devices anytime on campus due to regulations. Therefore, students may have visited Facebook in off-campus Internet cafes or through wireless and cellular networks provided by the two telecommunication companies in the Kingdom of Tonga. They may also have visited Facebook from home if Internet access was available.

Capacity. In this study, capacity refers to how well students utilize the Internet and Internet devices such as computers and smart devices. It also refers to how familiar students are with Facebook features and how they use these features to engage in Facebook activities. By using Facebook, students are able to gain experience with some features that are similar to those in an LMS (Table 2).

\section{Facebook Indicators of E-Readiness}

The Facebook indicators are used as measurement of the current degree of e-readiness or perceived skills (associated with e-learning) of the secondary students in the capital of the Island of Tonga, Nuku'alofa. Indicator A, indicates how many are on Facebook (Table 3). Perhaps if the percentage of A is low, familiar with Facebook features is also low. A difficulty of using the LMS may occur (according to Table 2). These Facebook indicators alone is not an indication whether these students are ready or have the desire to move towards e-learning, but an indication of the current perceived knowledge of the students. Other aspects of e-readiness must be indicated such as teachers' side, administrators and facility.

Table 4

Facebook Indicators

Facebook indicators of e-readiness

A. Users

B. Duration on Facebook by year(s)

C. Devices use: (Data must be inclusive)

D. Frequency of Facebook Visits

E. Average time spend on Facebook per visit

F. Favorite Facebook features

G. Mobile Access

H. Facebook group discussions participants (Data are inclusive)

I. Facebook page discussions participants (Data are inclusive)

J. Familiarity with Facebook features (description) 


\section{Survey Procedure}

Five secondary schools (A, B, C, D, and E; Figure 1) accepted the invitation to participate in the survey. These schools are located in the capital city of Nuku'alofa, where the two main offices of the only two telecommunications providers are located (X and Y). Surveyed students were randomly selected from these schools. Before students completed the paper-based survey, an explanation of the purpose of the survey was provided, including (a) the benefits of e-learning, (b) the importance of e-readiness, (c) and the relation of their Facebook experience to e-readiness and future development of e-learning in the Kingdom of Tonga. Students were given one day to fill out the survey, after which surveys were collected by school administrators.

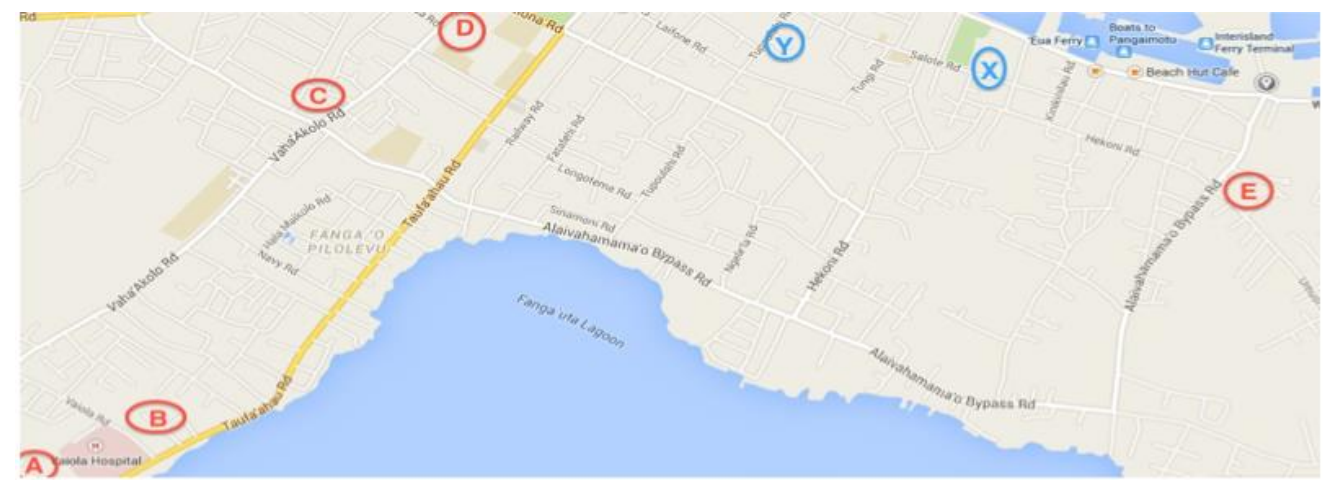

Figure 1. Locations of schools in Nuku'alofa, capital city of the Kingdom of Tonga. Image source: https://maps.google.com.

\section{Data Analysis}

Survey data were collected and entered into a LibreOffice spreadsheet. Part of the data were analyzed using Spearman coefficient correlation method which is provided in this spreadsheet.

\section{Results}

A total of 186 secondary students (63 males and 123 females) participated in the survey. Of these students, most of them $(n=150)$ were Facebook users and only a few $(n=36)$ were not Facebook users (Figure 2). Students were between 15-21 years of age (Figure 3), but most Facebook users were between 17-18 years of age. We also found that about 20\% of the student Facebook users had some experience of e-learning (Figure 4). 


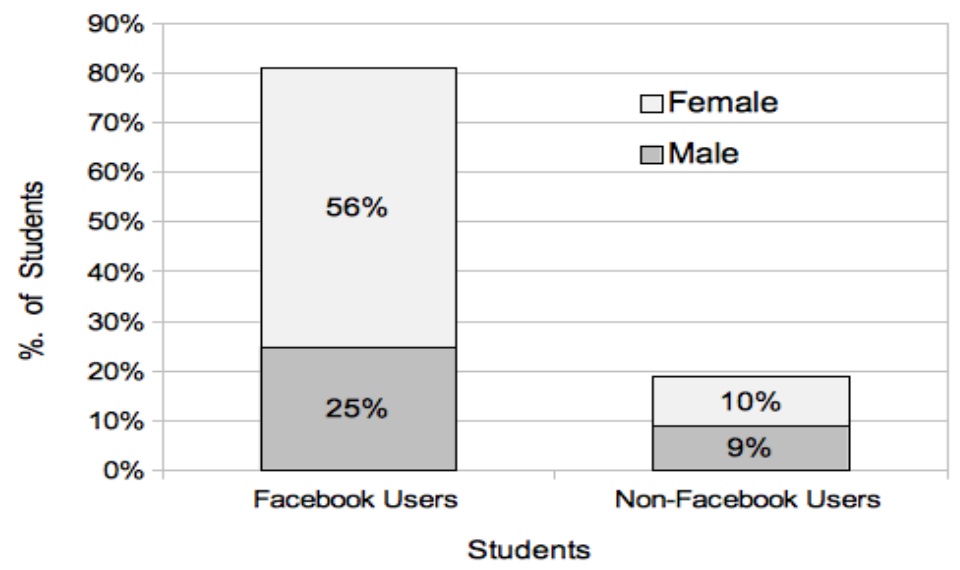

Figure 2. Student Facebook users versus non-Facebook users.

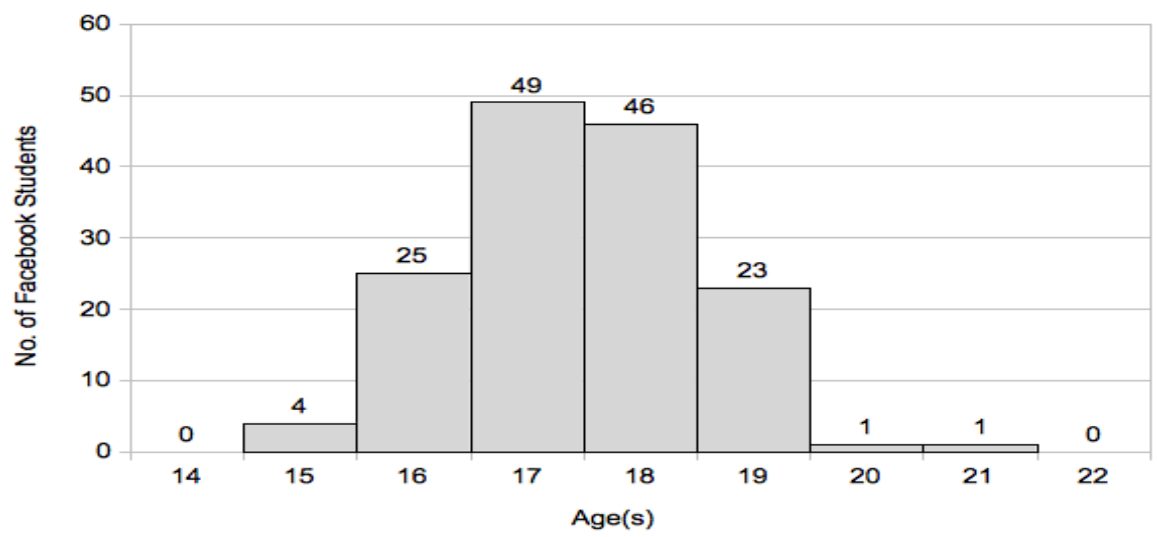

Figure 3. Age distribution of student Facebook users.

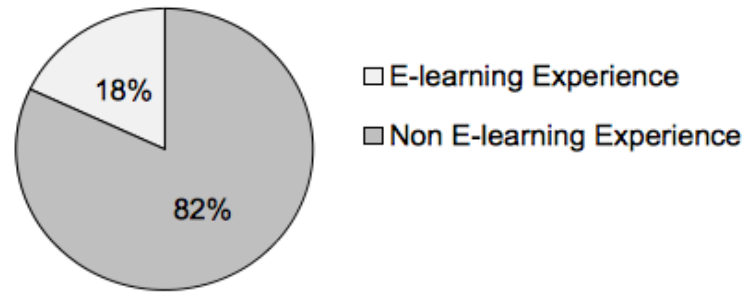

Figure 4. E-learning experience versus non e-learning experience students who use Facebook.

A shown in Figure 4, out of the $81 \%$ who were Facebook users, there were few with experience on elearning. As the objective(s) of this study, students with e-learning experience need not measure their degree of e-readiness for e-learning, for they have the experience; therefore, this study is focused on 
student Facebook users with no e-learning experience. The students with e-learning experience got their experience on e-learning from the (University of the South Pacific, 2015).

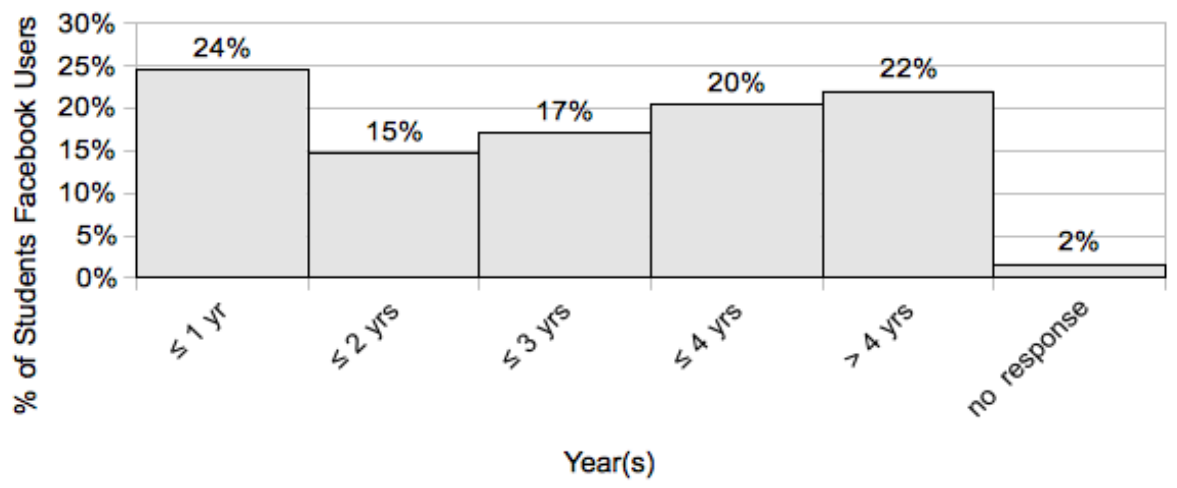

Figure 5. Duration of Facebook usage.

Most (74\%) student Facebook users had a Facebook account for more than 1 year (Figure 5). Although the remaining of Facebook users had used Facebook for 1 year or less, they may still have developed familiarity with the platform. Therefore, all students who used Facebook had some experience with Facebook features.

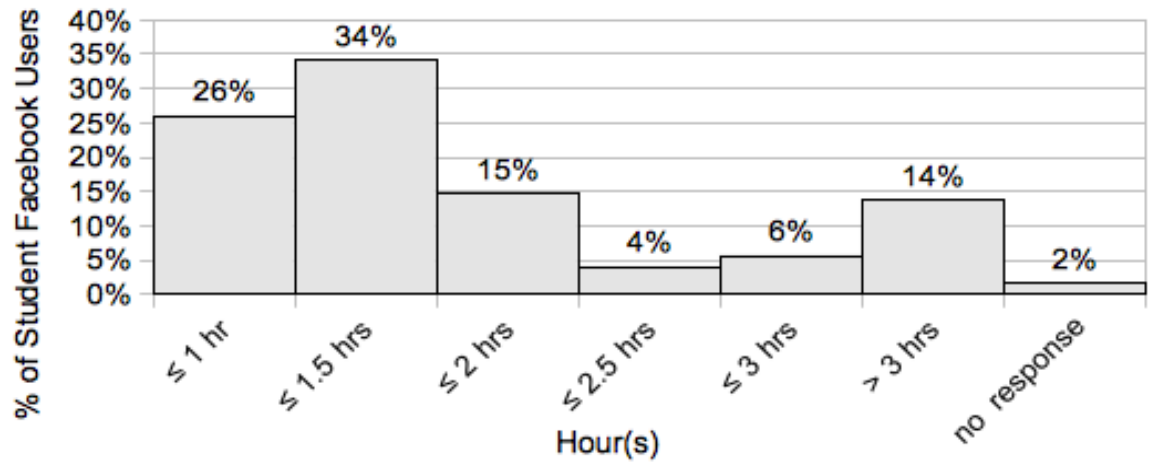

Figure 6. Average time spent on Facebook per visit.

Over half (60\%) of Facebook users spent less than and equal to 1.5 hours on Facebook per visit (Figure 6), perhaps due to the cost of using the Internet. Fewer Facebook users (39\%) spent more than 1.5 hour per visit; these students may have had the means to pay for Internet access through the use of Internet cafes or mobile phones. 


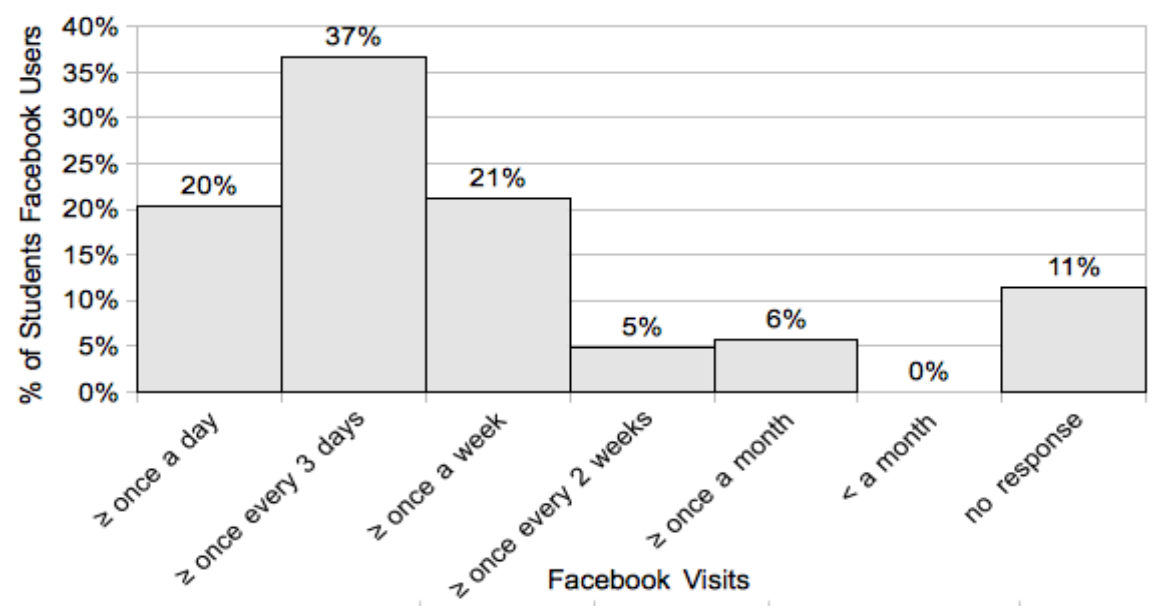

Figure 7. Frequency of Facebook visits.

Some of the student Facebook users accessed the site daily, whereas the majority (78\%) accessed the site at least once a week (Figure 7).

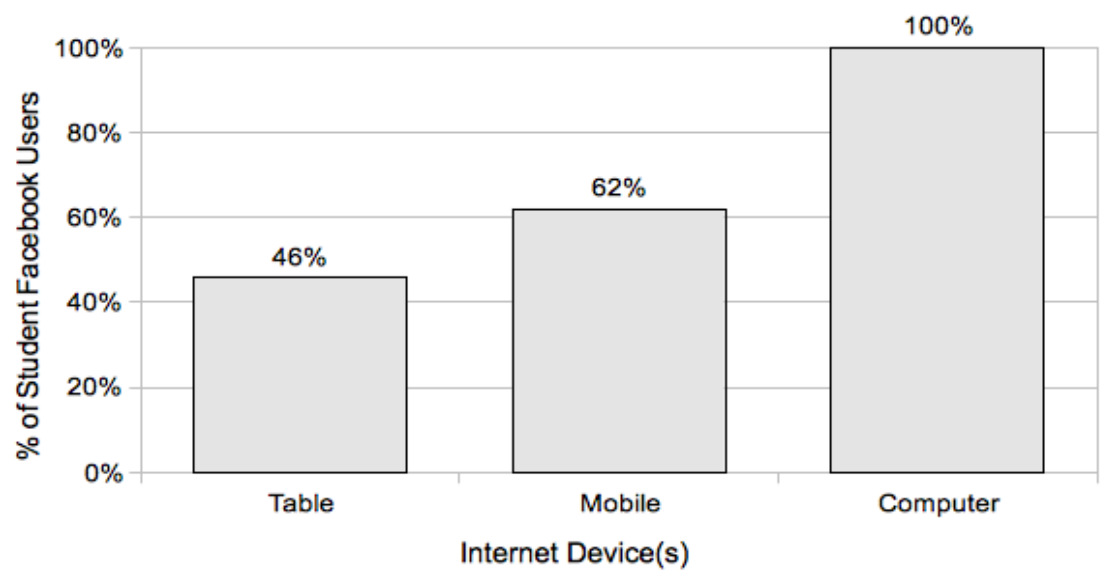

Figure 8. Internet devices used by students to access Facebook. Note that data are inclusive.

All student Facebook users accessed Facebook through a computer, although many students also accessed Facebook through a mobile phone or tablet (Figure 8). The capacity of these student Facebook users is built by spending time in front of three different screen versions: desktop, mobile, and the tablet version. 


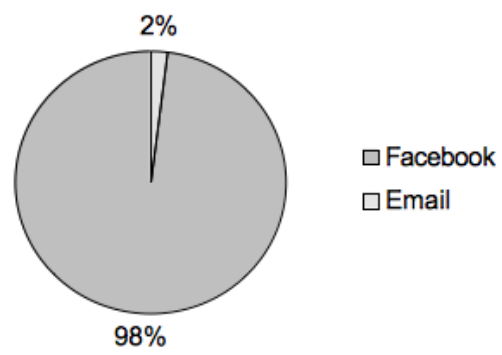

Figure 9. Most accessed account: Facebook versus e-mail.

Perhaps, most student Facebook users checked their Facebook account more often than their e-mail account (Figure 9), suggesting that student Facebook users spend most of their time on the Internet visiting Facebook.

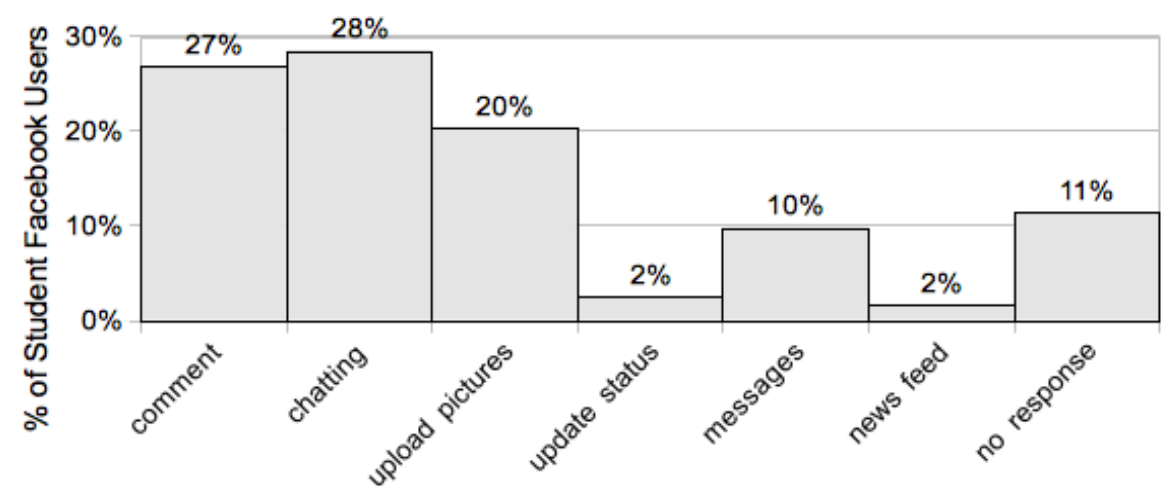

Figure 10. Students' favorite Facebook features. Note: data are exclusive.

Although student Facebook users were familiar with all Facebook features, they reported having a favorite Facebook feature (or most used; Figure 10). The chatting feature was the most favored of all.

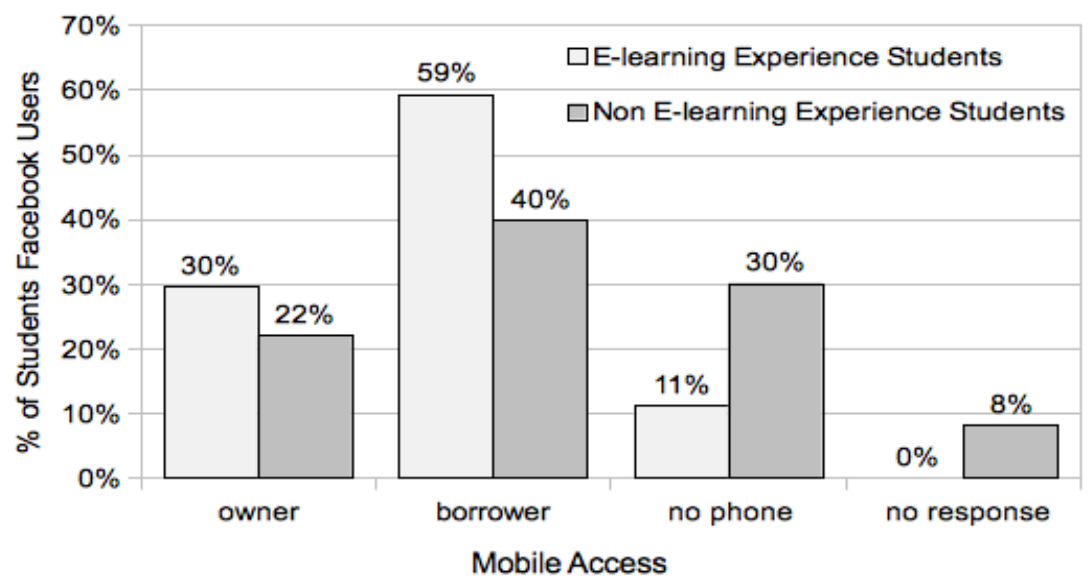

Figure 11. Mobile access to Facebook.

As Facebook is mobile friendly, some students used their own mobile phones or others' mobile phones to access Facebook (Figure 11). Significantly, e-learning experience students had high mobile access (89\%) 
compare to non e-learning experience students (66\%). E-learning experience students understood the convenience of using mobile devices to access an LMS, although they may have used the same mobile to access Facebook. Importantly, students accessed Facebook through mobile devices and they are familiar with the mobile version of Facebook.

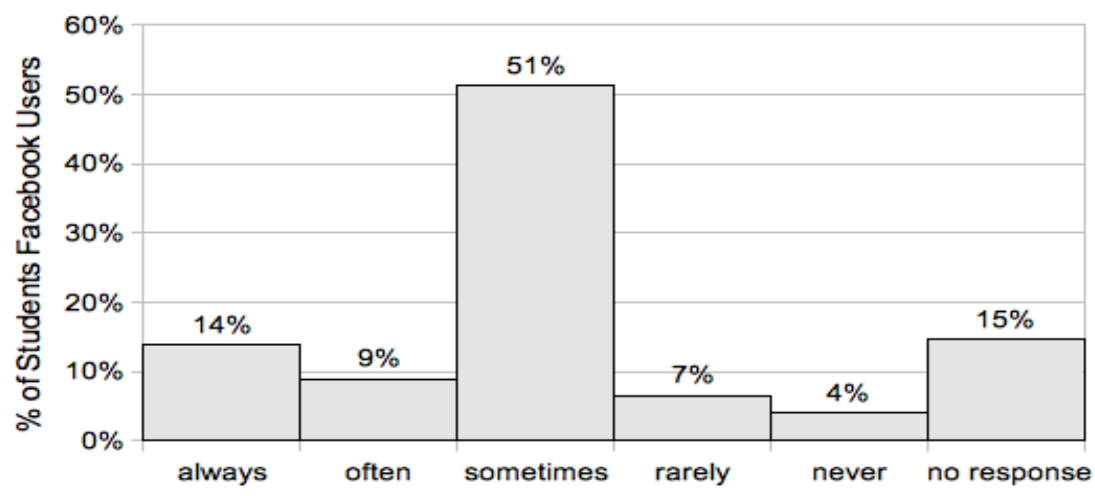

Figure 12. Facebook search option feature.

When student Facebook users were asked whether they use the search feature on Facebook, which allows users to search for people, places, Facebook groups, and Facebook pages, less than 20\% said they always used it, less than $10 \%$ said they often used it, most of them said they sometimes used it, and a few said they rarely used it (Figure 12).

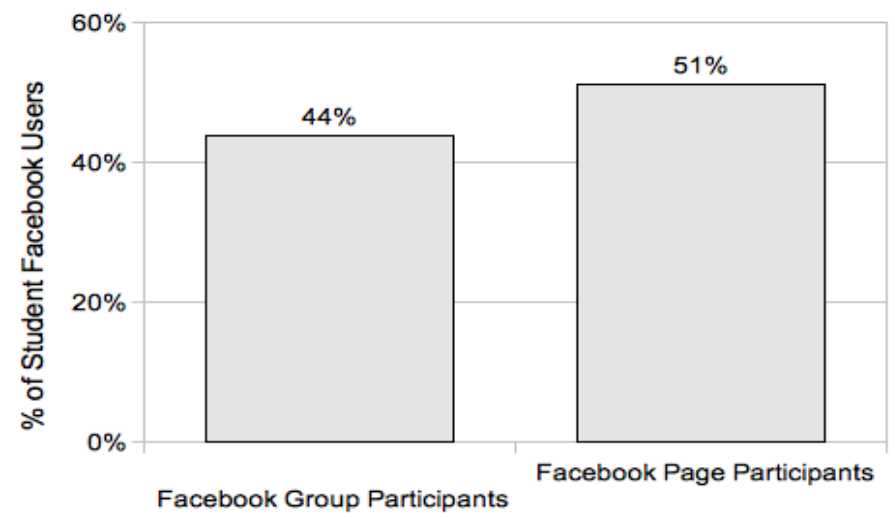

Figure 13. Participants in Facebook groups and Facebook pages. Note that data are inclusive.

When Facebook users were asked whether they use Facebook groups and Facebook pages, which allow users to participate in online discussions, more than $40 \%$ reported participating in Facebook group discussions, and about half of them reported following some Facebook pages (Figure 13). Such Web-based discussions can contribute to the development of students' reflective ability and critical thinking skills (Barnett-Queen, Blair, \& Merrick, 2005). 


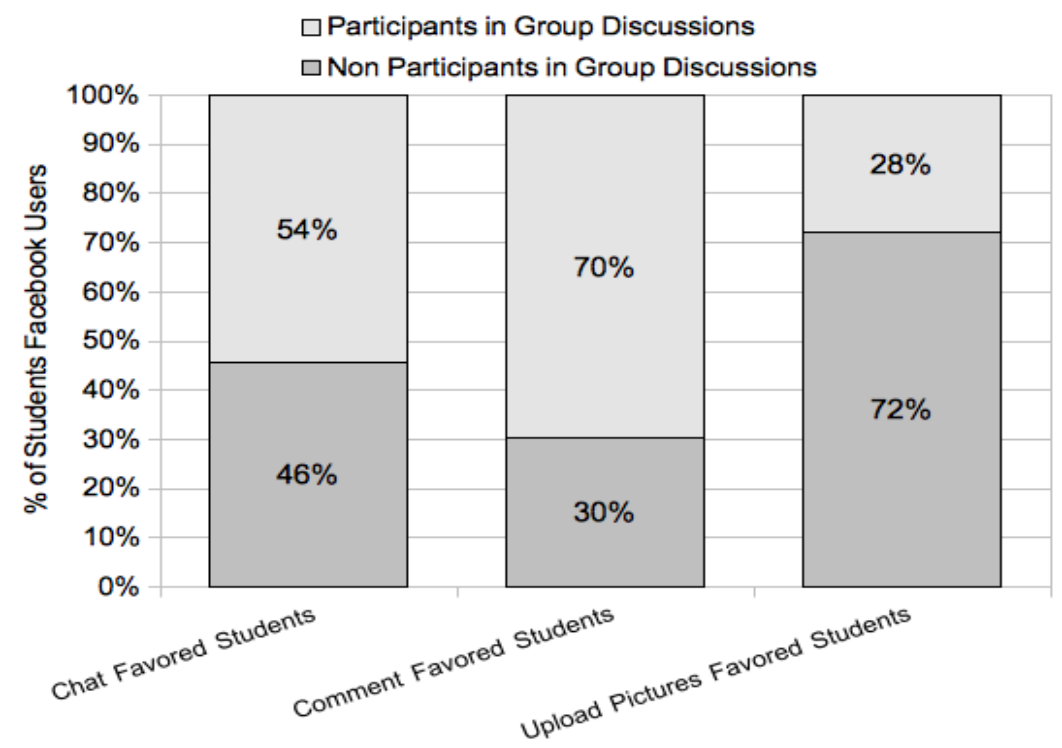

Figure 14. Participants in Facebook groups categorized by favorite Facebook features.

The group of students who favored the comments feature had the highest number of participants in Facebook groups discussions (Figure 14), suggesting that their favor of the comment feature fits group discussions. Whereas, over $50 \%$ of students who favored the chat feature participate in Facebook group discussions. Also, around $30 \%$ of students who favored the upload picture feature participate in Facebook group discussions.

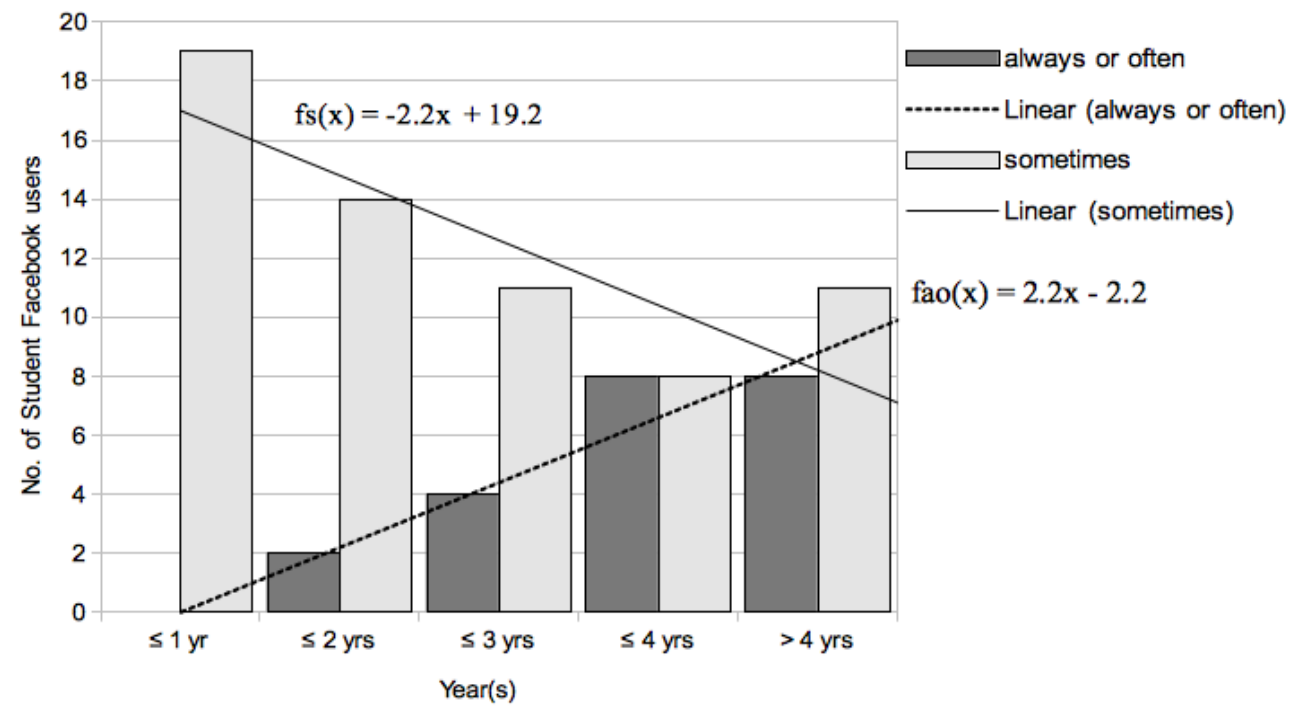

Figure 15. Correlation between duration on Facebook and numbers of students who sometimes, and always or often searched on Facebook. Note: fs(x) refers to the regression line for sometimes and fao(x) refers to the one for always or often. 
With longer durations of having a Facebook account, the number of students who sometimes used the search option declined ( $\rho=0.972$; Figure 15). However, the number of students who always or often used the search option increased with longer durations of having a Facebook account ( $\rho=-0.836$; Figure 15). Thus, familiarity with this Facebook feature could predict how students would use an LMS. That is, they may already know that using the search feature in an LMS would help them quickly find topics, contents, discussions, or other resources.

\section{Discussion}

According to Maugis et al. (2005), most e-readiness assessment tools assume a fixed, one-size-fits-all sets of requirements without considering the unique characteristics of particular countries or their demands for specific ICT applications. Following the suggestion by Dada (2006), we believed that moving the focus of e-readiness assessments from the country level to the user level can reveal e-readiness for e-learning among students in secondary schools. Our e-readiness assessment tool was designed according to the definition of e-readiness provided by UNESCO (2006), which focuses on the skillful utilization of technology by users. Based on this definition, we performed a survey of Facebook usage among secondary students in the Kingdom of Tonga to measure their e-readiness for e-learning, as many features of Facebook are similar to those of an e-learning system.

We found that most secondary students in the Kingdom of Tonga were Facebook users. Many of these students had a Facebook account for 2 or more years, accessed Facebook at least once a week, and spent a lot of time on Facebook making comments, participating in Facebook group discussions, chatting with Facebook friends, and uploading pictures. A longer duration of Facebook use was associated with a larger number of students who used the search option always or often, indicating that students understand the search function and thus may have become familiar with other Facebook features. Therefore, as students gradually become familiar with Facebook features, their digital literacy improves.

We also found that most secondary students access Facebook through mobile phones or tablets. This is important because mobile learning, or m-learning, is a recent trend in e-learning that increases the amount of time that students access online content (Caudill, 2007; Stern \& Taylor, 2007). As Sopu et al. (2013) faced the challenge of having a small number of computers available for secondary students to access an e-learning trial system, other types of mobile access to e-learning systems would be of great help. In 2011, Newsome and Comely proposed connecting the Kingdom of Tonga to a submarine fiberoptic or high-speed Internet network, which became available to the public in August 2013. However, insufficient bandwidth was a problem (Sopu et al., 2012). Fortunately, however, the student Facebook users in our survey enjoyed high-speed bandwidth through mobile phones, computers, and tablets. That secondary students are familiar with both mobile and desktop Facebook interfaces suggests that they would still be able to access online content without a computer, which might be an advantage for an elearning system in the Kingdom of Tonga. These student Facebook users access Facebook through mobile devices and still borrowed even if it was not a priority. The confidence of using Facebook or perhaps the curiosity about it made these students borrow a mobile from family and friends. This is also an indication 
that students may not be mobile subscribers (availability), but they are mobile users (usability) as proposed by UNESCO (2006).

In analyzing the pattern of Facebook usage, secondary students in the Kingdom of Tonga were often found to search for friends and relatives, Facebook groups, and old or new content uploaded to Facebook (Joinson, 2008). We also found that students participated in Facebook group discussions and listened to or watched new video content uploaded by Facebook friends. The chat and comment features were the favorite Facebook features of students. Mazman and Usluei (2010) describe three dimension of Facebook in education: communication, collaboration, and resource or material sharing. Our findings show that secondary students in the Kingdom of Tonga have experience with all three of these dimensions, which are necessary for participation in an e-learning system. Through their experience with Facebook features, secondary students should be able to quickly become familiar with an LMS, as their engagement with Facebook will have prepared them to meet minimum requirements for using an e-learning system in terms of digital literacy (Buck, 2012). Although other aspects of e-readiness for e-learning are needed to be observed in the Kingdom of Tonga, on the student side of e-readiness for e-learning, these indicators increase the level of confidence of students.

\section{Conclusion}

Theoretically, instead of identifying the percentage of Internet subscribers, Internet devices users or mobile subscribers, an observation of the capacity or the usability of the availability (access) by the secondary students only in the Kingdom of Tonga was conducted. Our results clearly point out that practically, it is possible to use Facebook experience (capacity) of secondary students to observe and measure some degree of e-readiness for e-learning in the Kingdom of Tonga, specifically in the capital area of Nuku'alofa. In other words, Facebook usage can serve as an indicator of the degree of e-readiness for e-learning among secondary students in the Kingdom of Tonga. In conclusion, students access Facebook often, spend a lot of time on Facebook, participate in various Facebook activities, and are familiar with the mobile version of Facebook, which may indicate a degree of digital literacy. The ereadiness for e-learning among secondary students in the Kingdom of Tonga appears to meet the basic necessary skills for participating in an e-learning system in the future. Moreover, the level of confidence is high when e-readiness for e-learning is estimated by Facebook usage. For future work, other aspects of ereadiness are needed to be observed in order to obtain the conclusion whether the Kingdom of Tonga is ready for e-learning in secondary level education.

\section{References}

Allin1Social. (n.d.). Facebook statistics worldwide. Retrieved from http://www.allin1social.com/facebookstatistics/countries/ 
Asian Pacific Economic Cooperation (APEC), E-Commerce Readiness Guide, Electronic Commerce Steering Group, (APEC). Retrieved from www.ecommerce.gov/apec 2000

Barnett-Queen, T., Blair, R., \& Merrick, M. (2005). Student perspectives of online discussions: Strengths and weaknesses. Journal of Technology in Human Services, 23(3-4), 229-244.

Beig, L., Montazer, G., \& Ghavamifar, A. (2007). Adoption a proper tool for e-readiness assessment in developing countries (case studies: Iran, Turkey and Malaysia). Journal of Knowledge Economy \& Knowledge Management, 2, 54-69.

Bradley, K. P., Holcomb, L. B., \& Smith, B. V. (2010). The use of alternative social networking sites in higher educational settings: A case study of the e-learning benefits of Ning in education. Journal of Interactive Online Learning, 9(2), 151-170.

Bridges.org. (2001). Comparison of e-readiness assessment models. Retrieved from http://www.internetpolicy.net/readiness/ereadinesscomparison.pdf

Bridges.org. (2005). E-readiness assessment: Who is doing what and where? Retrieved from http://www.infodev.org/infodev-files/resource/InfodevDocuments_3.pdf

Buck, A. (2012). Examining digital literacy practices on social network sites. Research in the Teaching of English, 43, 9-38. Retrieved from http://www.ncte.org/library/NCTEFiles/Resources/Journals/RTE/o471aug2012/RTE0471Examining.pdf

Bui, T. X., Sankaran, S., \& Sebastian, I. M. (2003). A framework for measuring national e-readiness. International Journal of Electronic Business, 1(1), 3-22.

Catherwood, V., Levine, V., \& Ministry of Education Planning Group. (2004). Tonga education policy framework 2004-2019. Retrieved from http://planipolis.iiep.unesco.org/upload/Tonga/Tonga Final-draft policy framework 20042019.pdf

Caudill, J. G. (2007). The Growth of m-learning and the growth of mobile computing: Parallel developments. International Review of Research in Open Distance Learning, 8(2). Retrieved from: http://www.irrodl.org/index.php/irrodl/article/view/348/873

Centre for International Development. (2000). Readiness for the networked world: A guide for developing countries. Harvard University. Retrieved from http://cyber.law.harvard.edu/readinessguide/guide.pdf

Chang, N. (2006). E-discussions as a complement to traditional instruction: did the students like online communication and why? Journal of Early Childhood Teacher Education, 27(3), 249-264. 
Chou, C. H., \& Pi, S. M. (2015). The effectiveness of Facebook groups for e-learning. International Journal of Information and Education Technology, 5(7), 477-82.

Commonwealth Connects. (2007). ICT strategic planning for the Kingdom of Tonga. Nuku'alofa, Tonga: Government of Tonga.

Dada, D. (2006). E-readiness for developing countries: Moving the focus from the environment to the users. Electronic Journal of Information Systems in Developing Countries, 27(6), 1-14. Retrieved from http://www.ejisdc.org/ojs2/index.php/ejisdc/article/download/219/184

Economist Intelligent Unit (2005). The Economist Intelligence Unit's quality of life index. Retrieved from http://www.economist.com/media/pdf/QUALITY_OF_LIFE.pdf

Eger, L. (2015). Is Facebook a similar learning tool for university students as LMS? Procedia-Social and Behavioral Sciences, 203, 233-238.

Fewkes, A. M., \& McCabe, M. (2012). Facebook: Learning tool or distraction? Journal of Digital Learning in Teacher Education, 28(3), 92-98.

Ghavamifar, A., Beig, L., Montazer, G. A. (2008). The comparison of different e-readiness assessment tools. In Proceedings of 3 rd international conference on information \& communication technologies: From theory to applications. Syria, IEEE.

Goertler, S. (2009). Using computer-mediated communication (CMC) in language teaching. Die Unterrichtspraxis, 42, 74-84.

Gu, L. L. (2014). Facebook, Twitter, \& QR codes: An exploratory trial examining the feasibility of social media mechanisms for recruiting youth participation to an online survey (Master's thesis), University of Rhode Island. Retrieved from http://digitalcommons.uri.edu/theses/462/

Joinson, A. N. (2008). 'Looking at', 'looking up' or 'keeping up with' people? Motives and uses of Facebook. In CHI 2008 proceedings (pp. 1027-1036). Retrieved from http://digitalintelligencetoday.com/downloads/Joinson Facebook.pdf

Kumpikaite, V., Duoba, K., \& Taraskevicius, A. (2011). Will such information technology as Facebook become regular mean for study process? In 2011 3rd international conference on advanced management science (Vol. 19, pp. 36-40). Retrieved from http://www.ipedr.com/vol19/7ICAMS2011-A00013.pdf

Purcell, F., \& Toland, J. (2004). Electronic commerce for the South Pacific: A review of e-readiness. Electronic Commerce Research, 4, 241-262.

Machado, C. (2007). Developing an e-readiness model for higher education institutions: Results of a focus group study. British Journal of Educational Technology, 38(1), 72-82. 
Mason, R. (2006). Learning technologies for adult continuing education. Studies in Continuing Education, 28(2), 121-133.

Meishar-Tal, H., Kurtz, G., \& Pieterse, E. (2012). Facebook group as LMS: A case study. International Review of Research in Open and Distributed Learning, 13(4), 33-48. Retrieved from http://www.irrodl.org/index.php/irrodl/article/view/1294/2295.

Maugis, V., Choucri, N., Madnick, S., Siegel, M., Gillett, S., Haghseta, F, ... Best, M. (2005). Global ereadiness for what? Readiness for e-banking. Information Technology for Development, 11, 4, $313-342$.

Mazman, S. G., \& Usluel, Y. K. (2010). Modeling educational use of Facebook. Journal of Computers \& Education, 55(2), 444-453. doi: 10.1016/j.compedu.2010.02.008

Mazer, J. P., Murphy, R. E., \& Simonds, C. J. (2007). I'll see you on Facebook: The effects of computermediated teacher self-disclosure on student motivation, affective learning, and classroom climate. Communication Education, 56(1), 1-17.

Molla, A., Cooper, V., Corbitt, B., Deng, H., Peszynski, K., Pittayachawan, S., \& Teoh, S. Y. (2008). Ereadiness to g-readiness: Developing a green information technology readiness framework. In Proceedings of the 19th Australasian conference on information systems 2008. Retrieved from https://researchbank.rmit.edu.au/eserv/rmit:2156/n2006009179.pdf

Mow, I. T. C. (2014). Issues and challenges, strategies and recommendations, in the development of ICT in a small island developing state: The case of Samoa. The Electronic Journal of Information Systems in Developing Countries, 63.

Mutula, S. M., \& van Brakel, P. (2006). An evaluation of e-readiness assessment tools with respect to information access: Towards an integrated information rich tool. International Journal of Information Management, 26(3), 212-223. doi: 10.1016/j.ijinfomgt.2006.02.004

Newsome, P., \& Comly, J., (2011). Initial environmental examination. TON: Tonga-Fïi submarine cable project. Nuku'alofa, Tonga: Tonga Cable Limited. Retrieved from http://www.adb.org/sites/default/files/project-document/61786/44172-01-ton-iee.pdf

Picci, L. (2006). The quantitative evaluation of the economic impact of e-government: A structural modelling approach. Information Economics of Policy, 18, 107-123.

Purcell, F., \& Toland, J. (2004). Electronic commerce for the South Pacific: A review of e-readiness. Electronic Commerce Research Research, 4, 241-262.

Rizk, N. (2004), E-readiness assessment of small and medium enterprises in Egypt: A micro study. Loyola University, Chicago. Retrieved from http://ecommons.luc.edu/cgi/viewcontent.cgi?article=105.5\&context=meea 
Socialbakers. (2014). Facebook stats for fans in Tonga. Retrieved from http://www.socialbakers.com/Facebook-pages/country/tonga/.

Stern, L. A., \& Taylor, K. (2007). Social networking on Facebook. Journal of the Communication, Speech \& Theatre Association of North Dakota, 20, 9-20.

Sopu, H. T., Chisaki, Y., \& Usagawa, T. (2012). Pre-stage analysis of first blended learning system in the Island Kingdom of Tonga secondary school. In Proceedings of Japan Society of Education Technology (JSET). Nagasak University, Nagasaki, Japan

Sopu, H. T., Chisaki, Y., \& Usagawa, T. (2013). Experience of e-learning of pilot e-learning system at the secondary school in the island of Tonga. In Proceeding of International Engineering Symposium. Kumamoto University, Kumamoto, Japan

Sopu, H. T., Chisaki, Y., \& Usagawa, T. (2014). The attractiveness of Facebook in secondary students in the kingdom of Tonga and its potential. In Advanced Applied Informatics (IIAIAAI), 2014 IIAI 3rd International Conference on (pp. 510-516). IEEE. DOI: 10.1109/IIAI-AAI.2014.107

TDoS. (2011). Economic statistics of Tonga. Retrieved from http://tonga.prism.spc.int/.

Teo, T., \& Wong, S. L. (2013). Modeling key drivers of e-learning satisfaction among student teachers. Journal of Educational Computing Research, 48(1), 71-95.

The Technology CEO Council (TCC). (n.d.). Retrieved from http://www.techceocouncil.org/ .

UNESCO. (2006). E-readiness in the Asia Pacific Region Tonga. Bangkok, Thailand: CAVAL Collaborative Solutions.

United Nations. (2014). E-government survey 2014: E-government for the future we want. Retrieved from http://unpan3.un.org/egovkb/en-us/Reports/UN-E-Government-Survey-2014.

University of the South Pacific. (2015). Degree disciplines - major/minor. Retrieved from https://www.usp.ac.fj/index.php?id=programs.

University of the South Pacific. (2005). ICT in secondary education in the Pacific Region: Status, trends and prospects. Retrieved from https://www.usp.ac.fj/jica/ict research/documents/pdf files/ICT in Secondary Education in the Pacific Region.pdf.

Vaezi, S. K., \& Bimar, H. S. I. (2009). Comparison of e-readiness assessment models. Scientific Research and Essay, 4(5), 501-512.

Wang, Q., Woo, H. L., Quek, C. L., Yang, Y., \& Liu, M. (2011). Using the Facebook group as a learning management system: An exploratory study. British Journal of Educational Technology, 43(2), 428-438. 
World Bank. (2014). World development indicator. Retrieved from

http://data.worldbank.org/country/tonga.

Athabasca

University

(c) (†) 